\title{
HISTORY OF BIOETHICS IN PROFESSIONAL NURSING EDUCA- TION: A SPANISH VIEW
}

\author{
Marta Elena Losa Iglesias' ${ }^{1}$ Ricardo Becerro de Bengoa Vallejo ${ }^{2}$
}

\begin{abstract}
Nursing education and the nursing profession must go hand by hand to emphasize efforts to improve knowledge in ethical decision-making and professional deontology. The nursing profession in Spain has struggled for legislation of the profession as well as a professional code of ethics. Based on the ethical specifications for nursing practice, it is evident that education in nursing ethics is of the most importance and should be emphasized as an integral component of higher-level nursing education. Nursing schools should seek to establish programs that effectively integrate the humanities with the biotechnological aspects of the profession and define strategies for monitoring nursing professionals who graduate from those schools.
\end{abstract}

Key words: bioethics, nursing education

\section{Historia de la bioética en la educación profesional de enfermería: una visión espańola}

Resumen: La enseñanza y la profesión de enfermería deben ir de la mano para enfatizar la mejora del conocimiento en deontología y la toma de decisiones éticas y profesionales. La profesión de enfermería en Espańa ha luchado por tener su propia legislación profesional, así como un código ético. Para la práctica de enfermería, es evidente que la educación en ética debe tener una gran importancia y debe ser un componente integral de la educación en enfermería universitaria. Las escuelas de enfermería deben tratar de establecer programas que integren de forma efectiva las humanidades con los aspectos biotecnológicos propios de la profesión, y definir estrategias de seguimiento y formación continua para los profesionales egresados.

Palabras clave: bioética, educación de enfermería

\section{História da bioética na educaçáo do profissional de enfermagem: uma visão espanhola}

Resumo: O ensino e a profissão de enfermeiro devem se dar as mãos para enfatizar a melhoria do conhecimento em deontologia e a tomada de decisóes éticas e profissionais. A categoria de enfermeiro na Espanha lutou para ter sua própria legislação profissional, assim como um código ético. Para a prática de enfermagem é evidente que a educação em ética deve ter uma grande importância e deve ser um componente integral da educação em enfermagem universitária. As escolas de enfermagem devem tratar de estabelecer programas que integrem de forma efetiva as humanidades com os aspectos biotecnológicos próprios da profissão, e definir estratégias de seguimento e formação contínua para os profissionais egressos dos cursos de enfermagem.

Palavras-chave: bioética, educação em enfermagem

\footnotetext{
${ }^{1}$ Facultad de Ciencias de la Salud, Universidad Rey Juan Carlos, Madrid, Spain Correspondencia: marta.losa@urjc.es

${ }^{2}$ Facultad de Enfermería, Universidad Complutense, Madrid, Spain
} 
Advances in science, technology, and pharmaceutical treatments have overwhelmed ethics(1). This inexorable technological progress has resulted in a progressively widening gap between those who believe that human values and laws alone must somehow regulate the advancement of science, and those who are convinced that the evolution of mankind, biotechnology, and science should be permitted and supported without restriction(2). This latter view reveals a clearly anthropocentric perspective grounded in beliefs in the greatness of the human race, in the power of the mind over biological structures and processes, and in the supremacy of intelligence over morality. On the one hand, these major developments have produced a sense of awe and admiration, as well as fear of the potential tyranny, ungovernability, and dominance of the relatively small group of people who make up the scientific community. On the other hand, they have spawned the dilemma of accepting and supporting these developments in the face of pressure from religious and other beliefs that portray biotechnology as signaling the advance of the "evil empire," the loss of values, and a lack of regard for human dignity. Bioethics, a term coined by Potter, is concerned with building a bridge between the two entities, bios and $e$ thos(3).

Does this situation affect the work of the nurse? Of course, the nurse must face this difficulty every time she serves on a scientific health-care team or participates actively in research, in direct patient care, in teaching, in defining government policies, and in the implementation of disciplinary codes, among others. Bioethics has emerged, then, as a field of study concerned with ensuring that these substantial and important scientific advances are balanced by a sense of responsibility and respect for other human beings as well as for life itself(4). Bioethics seeks and contributes solutions to the emerging dilemmas that are morally permissible and legally framed, as in the case of the United Nations and its Educational, Scientific, and Cultural Organization (UNESCO), whose aim is to reach agreements that allow the regulated advance of science while preserving its commitment to humanity, all forms of life, the environment, and the biosphere, as well as emphasizing the responsibility of the more-developed countries to- ward the less-developed ones(5).

Throughout history, going all the way back to the principles laid out in Aristotle's Nicomachean Ethics (Aristotle, trans. 1908)(6), moral values and ethical principles have regulated the actions of health-care personnel and their relationships with patients. But is this what society expects of us? Why is it necessary to teach bioethics? How is bioethics learned? Medicine and nursing, in their eagerness to study man, his complexity, scientific advances, and economic trends, have left to one side the study and enrichment of human spirituality. Indeed, they have underestimated the importance of the study of the humanities in general, producing in most cases a loss of sensitivity to the actual situation of the patient and of the community $(3,7)$.

If we focus on the nursing student and consider the scant interest shown by nursing students in ethics, at least as it is traditionally taught, it is valid to propose that bioethics be learned, in the context of contemporary education, as a tool that will allow the nurse to acquire from the earliest years of his or her professional career not only a special sensitivity for what happens in the immediate environment, but also a broad perspective of the wider world, with reference to its plurality and diversity $(7,8)$. The teaching of bioethics must include theoretical ethical concepts, but such theoretical knowledge is not sufficient; acting ethically requires internalization of the meaning of these concepts and the construction of a moral conscience. Thus, ethics should be taught not only to ensure that students are aware of ethical principles and can recognize ethical and unethical behavior, but also to achieve a favorable change in their own behavior that will be encouraging to the patient(9). This teaching of bioethics should be continuous and must allow for smallgroup discussion of cases of interest to students to enhance dialogue between students and faculty members $(3,7)$.

The training of nurses must certainly address the classic scientific, clinical, biotechnological, research, administrative, and management themes, but the survival of the nursing profession demands that emphasis be placed on social problems, coexistence of a diverse population, 
solidarity, principles and values, and, most important, caring for oneself, for others, and for nature and the environment(10). Above all, the teaching of bioethics must reinforce the student's respect for human dignity and life. The bioethics curriculum should include educational models that not only teach the knowledge, skills, and attitudes required for the competent delivery of health care, but also guide the student to acquire the ability to solve problems, to be able to independently seek needed information, and thus be transformed into a true professional. The nursing student must receive all the information and education needed to enable her to develop in her imagination a broad, universal, prejudicefree conception of ethical dilemmas that she will face in the course of her student life and in the development of her professional career, be it in research, teaching, management, business, or other arenas(11). The nurse must become sensitive to poverty, hunger, injustice, violence, and corruption, but especially to inequality, the pain and suffering of the less fortunate. In short, the nurse must become the defender of the rights of the patient: the patient's advocate(12).

In order to be an effective member of multidisciplinary teams, the nurse must keep in mind that although she works closely with physicians, she is a professional, with her own competencies to demonstrate and ethical standards to meet. The nurse should understand that her personal responsibility is not diluted in that of the doctor, and that her actions cannot be defended by the concept of carrying out medical orders $(10,13)$. Nurses must deal constantly with ethical dilemmas related to contraception and natural regulation of fertility, abortion, assisted reproduction, the dilemmas of old age, pain and death, palliative care, euthanasia and the right to die with dignity, the distribution of resources, defense of patient autonomy, research, the nurse-patient relationship, informed consent, professional confidentiality, communicating honestly with the sick, responsibility toward other health-care professionals and patients, and the humanization of care. Each of these issues can compromise and jeopardize the nurse's actions $(14,15)$.

The nursing profession in Spain has struggled for legislation of the profession as well as a professional code of ethics to ensure that nurses themselves are the judges of actions among their ranks that could have a negative impact on the nursing profession(16). A 2003 law on the health professions in Spain defines the nursing profession as "correspond[ing] to the university degree in nursing management, evaluation, and provision of nursing care aimed at the promotion, maintenance, and recovery of health and the prevention of diseases and disabilities"(17). This same law states that disciplinary problems with regard to ethics will be addressed by the General Council of each profession (in this case the nursing profession), which applies its own penalties under its particular code of ethics, regardless of any other civil or penal sanctions that the Spanish courts might apply to such criminal acts. For example, Chapter 10, Article 56 of the Code of Ethics of Spanish Nurses states that "the nurse takes responsibility for all decisions at the individual level that must be taken in exercising the profession"; hence the decisions, as well as their consequences, must be documented. In the absence of documentation or owing to negligent actions deriving from this lack, the nurse's own profession can apply sanctions according to the Code of Ethics, but the civil and criminal justice systems may also penalize the nurse for negligence in the practice of her profession if it results in harm to others(18).

Based on the ethical specifications for nursing practice, it is evident that education in nursing ethics is of the utmost importance and should be emphasized as an integral component of higherlevel nursing education(18). Nursing schools should seek to establish programs that effectively integrate the humanities with the biotechnological aspects of the profession and define strategies for monitoring nursing professionals who graduate from those schools. Nursing education and the nursing profession must go hand by hand to emphasize efforts to improve knowledge in ethical decision-making and professional deontol$\operatorname{ogy}(11)$.

Currently, a new, harmonized model of higher education is emerging in Europe(19). In recent years, the creation of the European Higher Education Area has prompted profound changes within the Spanish university system conducive 
to the standardization of university qualifications in order to allow free movement and exchange of students and graduates among countries. New plans will soon be implemented that will lead to changes in the structure and organization of educational materials, in the methodology of granting credit with particular emphasis on learning methods, and in the procedures for assessing skills(20). Beginning in 2010, these changes will bring greater uniformity of nursing education across Europe. The new graduate programs in nursing are considering the integration of the subjects of deontology and professional ethics into the nursing curriculum. This will ultimately result in a higher level of knowledge among European nursing students of bioethics, professional ethics, and professional deontology (21). 
References

1. Malo-Fletcher N. Ethically Authentic: Escaping Egoism Through Relational Authenticity. Dissertation at Depatment of Philosophy, Faculty of Arts, University of Ottawa, 2011.

2. Noble DF. America by Design: Science, Technology, and the Rise of Corporate Capitalism. New York: Oxford University Press; 1979.

3. Beauchamp TL, Childress JF. Principles of biomedical ethics ( $4^{\text {th }}$ ed.). New York: Oxford University Press; 1994.

4. Sharpe VA. Science, bioethics and the public interest: On the need for transparency. Hastings Center Report 2002; 32: 23-26.

5. Berlinguer G, De Castro L. Report of the IBC on the Possibility of Elaborating a Universal Instrument on Bioethics. Paris: International Bioethics Committee, UNESCO; 2003.

6. Aristotle. Nicomachean ethics (W.D. Ross, Trans). Oxford: Clarendon Press; 1908.

7. Echeverri de Pimiento S. Medicina como institución: entre la codicia y el suicidio. Bogotá: Editorial Kimpres; 2004.

8. Gracia D. Fundamentos y enseñanza de la bioética. In: Ética y vida: estudios bioéticos. Bogotá: Editorial El Búho; 2000.

9. McCarthy J. A pluralist view of nursing ethics. Nurs Philos 2006; 7: 157-164.

10. Pastor García LM, León Correa FJ. Manual de ética y legislación en enfermería. Madrid: Mosby; 1997.

11. Losa Iglesias ME, Becerro de Bengoa Vallejo R, Palacios Ceña D, Fuentes PS. Knowledge and positions on bioethical dilemmas in a sample of Spanish nursing students: a questionnaire study. Contemp Nurse 2011 Apr-Jun; 38(1-2): 18-23.

12. Cameron C. Patient advocacy: a role for nurses? European Journal of Cancer Care 1996; 5: 81-89.

13. Polaino-Lorente A. Manual de bioética general. Madrid: Editorial Rialp S.A.; 1994.

14. McCabe H. Nursing involvement in euthanasia: A 'nursing-as-healing-praxis' approach. Nurs Philos 2007; 8: 176-186.

15. Phillips S. Ethical decision-making when caring for the noncompliant patient. Journal of Infusion Nursing 2006; 29: 266-271.

16. Consejo General de Enfermería de España. Resolución no 32/89 1989. Retrieved August 13, 2011, Available in: http:// www.cge.enfermundi.com/servlet/BlobServer?blobcol=urldata\&blobheader=application/pdf\&blobkey=id\&blobtable= MungoBlobs\&blobwhere $=1148974690384 \&$ cachecontrol=immediate\&csblobid=Iji0hqS6rBRzxTLWXU9dq1tM6AI tm8siO37M3Yjml3Z2ampCo2m1!1821920645!1218650676409\&target=_blank

17. Boletín Oficial del Estado. Ley 44/2003, de 21 noviembre, de la certificación de las profesiones sanitarias. Retrieved August 13, 2008, Available in: http://www.boe.es/g/es/bases_datos/doc.php?coleccion=iberlex\&id=2003/21340

18. Milton CL. Ethics content in nursing education: Pondering with the possible. Nurs Sci Q 2004; 17: 308-311.

19. European Commission. Bologna Declaration: Joint Declaration of 19 June 1999 of the European Ministers of Education. Retrieved August 13, 2011. Available in: http://www.crueuta.info/web_crue/docs/declaracion_bolonia.pdf.

20. De Miguel Díaz M. Adaptación de los planes de estudio al proceso de convergencia europea. Oviedo, Spain: Universidad de Oviedo, 2004. Retrieved August 13, 2011. Availble in: http:/www.ub.es/geologia/recursos/documents/6\%20 Planes\%20de\%20estudio\%20ante\%20el\%20EEES\%20MEC\%202004.pdf

21. Boletín Oficial del Estado. Resolución de 14 de febrero de 2008 de la Secretaría de Estado de Universidades e Investigación. Retrieved August 13, 2011. Availble in: http://www.boe.es/boe/dias/2008/02/27/pdfs/A11605-11606.pdf.

Recibido: 2 de mayo de 2012

Aceptado: 16 de junio de 2012 